\title{
The Case for Normothermic Machine Perfusion in Liver Transplantation
}

\author{
Carlo DL Ceresa ${ }^{1}$, David Nasralla ${ }^{1}$, Constantin-C Coussios ${ }^{2}$, Peter J Friend ${ }^{1}$
}

1. Nuffield Department of Surgical Sciences, University of Oxford, Oxford, UK

2. Institute of Biomedical Engineering, University of Oxford, Oxford, UK

Key words: Preservation, Utilisation, Marginal, Ischaemia Reperfusion Injury, Viability Assessment

\begin{abstract}
In recent years there has been growing interest in normothermic machine perfusion as a preservation method in liver transplantation. In most countries, due to a donor organ shortage, an unacceptable number of patients die whilst awaiting transplantation. In an attempt to increase the number of donor organs available, transplant teams are implanting a greater number of high-risk livers; including those from donors after circulatory death, older donors and with steatosis. Normothermic machine perfusion maintains the liver ex vivo on a circuit by providing oxygen and nutrition at $37^{\circ} \mathrm{C}$. This permits extended preservation times, the ability
\end{abstract}

1) Abbreviations: AST, aspartate aminotransferase; ATP, adenosine triphosphate; COPE, Consortium for Organ Preservation in Europe; DBD, donor after brain-stem death; DCD, donor after circulatory death; EAD, early allograft dysfunction; IRI, ischaemia reperfusion injury; NMP, normothermic machine perfusion; SCS, static cold storage

2) Carlo DL Ceresa is supported by the Medical Research Council clinical research training fellowship

3) Conflict of Interest: Peter J Friend and Constantin-C Coussios are full-time academics at the University of Oxford and also chief medical officer and chief technical officer, respectively, and shareholders in OrganOx Ltd, a spin-out company from the University of Oxford.

Carlo DL Ceresa and David Nasralla have received consultancy income from OrganOx Ltd. for assisting with the testing of the normothermic liver perfusion device and for carrying out normothermic organ preservation out-of-hours.

4) Correspondence to Peter J Friend MD, The Oxford Transplant Centre, Churchill Hospital, Headington, Oxford, UK, OX3 7LE. Tel: +44 1865 223872; e-mail: peter.friend@nds.ox.ac.uk 
to perform liver viability assessment and the potential for liver-directed therapeutic interventions during preservation. It is hoped that this technology may facilitate the enhanced preservation of marginal livers with improved post-transplant outcomes by reducing ischaemia reperfusion injury. Clinical trials have demonstrated its short-term superiority over cold storage in terms of early biochemical liver function and it is anticipated that it may result in increased organ utilisation, helping to reduce the number of waiting list deaths. However, further studies are required to demonstrate longer-term efficacy and the impact on biliary complications as well as further knowledge to exploit and maximise the potential of this exciting new technology.

\section{Introduction}

Preserving organs under physiological conditions is not a new concept. In 1935, Alexis Carell and Charles Lindbergh developed a perfusion chamber for the normothermic preservation of organs and demonstrated their viability when perfused with oxygenated serum at $37^{\circ} \mathrm{C}$ for several days (1). However, due to its complexity, the technique was not widely adopted. Later, in the 1960s, several groups explored machine perfusion as a method of dynamic liver preservation but with complex logistical considerations and the advent of simple and effective static cold storage solutions (3), interest waned. Now, some 50 years later, the transplant community has seen a resurgence in enthusiasm for machine perfusion of organs. This is largely due to the need to expand the donor pool by successfully transplanting marginal organs. In this review article, we will focus on normothermic machine perfusion (NMP) and its role in liver preservation and transplantation.

\section{The Need for New Technology}

At present, liver transplantation's potential as a life-saving treatment option for patients with end-stage liver disease is limited by a shortage of available donor organs. A paucity of livers in the deceased donor pool results in a concerning number of patients, around $15-20 \%$ in the US and UK $(4,5)$, dying whilst on the waiting list. Changes in donor demographics compound the issue; with improvements in road safety and medical care leading to a highly desirable reduction of "ideal" younger donors, and the necessary move to older donors with more advanced co-morbidities (6). The world-wide obesity epidemic results in a greater number of donors with incidental hepatic steatosis (7), further contributing to the number of marginal livers in the donor pool. The number of livers from donors after circulatory death (DCD) is 
also increasing; particularly in the UK, where $42 \%$ of the donor pool and $21 \%$ of transplants are made up of DCD livers (8). Unfortunately, graft loss and recipient mortality have been shown to be almost twice as high with DCD livers (9) and their use, therefore, remains limited. In order to bridge the gap between supply and demand for livers, more marginal livers are being transplanted with the accepted risk of increased complications such as primary non-function and ischaemic cholangiopathy $(10,11)$. The need to safely and reliably transplant more livers without compromising the outcome provides a powerful incentive for innovation, and thus the resurgence in interest in NMP, which has rapidly come to the fore in recent years.

\section{Mechanism of Action}

Static cold storage (SCS) is the standard-of-care preservation method in liver transplantation. The aim is to maintain structural and functional integrity of the liver so as to promote function at reperfusion. This is achieved through cooling to $4^{\circ} \mathrm{C}$ with preservation solution which decreases cellular energy consumption by reducing the metabolic demand of the tissue. The composition of the preservation solution aims to reduce cell swelling and lysis associated with cooling. A primary objective of preservation is to attenuate ischaemia-reperfusion injury (IRI) which results from the efflux of accumulated metabolic products formed during ischaemia, resulting in a profound inflammatory immune response on reperfusion, causing hepatocellular injury. For a low-risk liver, SCS is an adequate preservation method as these livers are able to tolerate the modest levels of IRI with satisfactory post-transplant outcomes and survival rates. However, marginal livers tolerate ischaemia poorly, experiencing a more severe inflammatory response and reperfusion injury resulting in poor short and long-term outcomes.

NMP maintains the liver ex vivo in a fully functioning state, providing it with oxygen and nutrients at $37^{\circ} \mathrm{C}$. Several NMP circuits have been described in detail (12-16); these function on the principle of physiological preservation which maintains cellular metabolism throughout the preservation period. Principal components include: blood reservoir; pump(s) (some circuits comprise two pumps, for portal venous and hepatic arterial flow); an oxygenator; and, a heat exchanger. A comparison of the devices which are either commercially available or used in clinical trials is shown in table 1. NMP's superiority over SCS in terms of synthetic and metabolic liver function and post-transplant survival has been shown in large animal models $(13,14)$ through evidence of ex vivo bile production, reduction of markers of cell injury and post-transplant survival. However, the precise mechanism(s) underpinning the beneficial effects of NMP have not yet been fully elucidated. It is likely that perfusion helps maintain a 
healthy endothelium and replenish adenosine triphosphate (ATP). The importance of increasing hepatic ATP in human liver transplantation has previously been shown, with a direct correlation between high hepatic ATP content and good post-transplant outcomes (17). NMP's role in ATP regeneration has been confirmed in murine experiments where rapid ATP recovery following initiation of NMP has been demonstrated $(18,19)$ as well as mitochondrial ATPase activity (20). More recently, human studies have demonstrated histological evidence of glycogen repletion during NMP (21). Glycogen is essential to maintain hepatocellular integrity and function by supplying glucose for ATP generation. Once glycogen is consumed, ATP depletion ensues, leading to irreversible cell injury and necrosis (22). In order to further exploit and maximise NMP's potential, a sound understanding of the injury and repair pathways affected during preservation will be important. This may be aided by a multiplatform -omics approach in combination with computational biology (23).

\section{Clinical Experience of NMP}

In recent years, clinical experience of NMP has grown and the body of evidence supporting the beneficial impact of NMP in liver transplantation has increased. The first NMP livers were transplanted as part of a phase one study undertaken by Ravikumar et al which demonstrated the safety and feasibility of NMP from retrieval to transplantation, including transportation (24). This was the first study to report post-transplant outcomes from livers preserved by NMP. As well as safety and feasibility (the primary purpose) this trial demonstrated a significant biochemical benefit in the form of a halving of peak serum aspartate aminotransferase (AST) when compared to matched controls preserved via SCS. The peak serum AST in the first 7days post-transplant is a validated surrogate marker for graft and patient survival (25-27). Two further pilot studies were subsequently performed by Selzner et al (28) and Bral et al (29) which once again demonstrated the safety and feasibility of the technology and compared posttransplant outcomes to cold-stored controls. Selzner and colleagues demonstrated a nonsignificant reduction in peak serum AST in the NMP-preserved livers compared to retrospective SCS controls but this finding was not achieved by Bral and colleagues, in whose study there was a non-significant increase in the median peak serum AST in the NMP cohort. It is important to note that none of these studies was either randomised or powered to demonstrate a difference in outcomes. Across these three studies, only one graft was lost during preservation. This was due to an occult twist in the portal vein which was obscured within the hepatic hilum, compromising perfusion of the liver (29). A summary of published studies from 
livers transplanted following NMP is shown in table 2. A phase 3 multi-centre randomised controlled trial to compare the efficacy of NMP versus SCS in liver transplantation was recently conducted by the Consortium for Organ Preservation in Europe (COPE; www.copeeu.org). A total of 222 livers were transplanted as part of the study (121 NMP, 101 SCS) with the primary endpoint of difference in peak serum AST between the two treatment arms. Data from a published abstract (30) demonstrates that the study achieved its primary endpoint with a significant reduction in peak serum AST in the NMP group (974 IU/L SCS vs 485IU/L NMP; $p<0.001$ ). There was also a significant reduction in early allograft dysfunction (EAD), another surrogate marker of graft outcome, in livers preserved via NMP (29.9\% SCS vs 12.6\% NMP; $\mathrm{p}=0.002)$. Another notable finding was that of a reduced rate of liver discard in organs randomised to NMP and there was a significant difference between the two groups (32 SCS vs 16 NMP; $\mathrm{p}=0.01$ ). Although, to date, no trial has shown an improvement in patient or graft survival, or reduction in biliary complications, it is notable that trials with much larger numbers and longer-term follow-up would be required to test these outcomes. Even if the sole benefit of NMP were shown to be improved organ utilisation with superior early biochemical function when compared to SCS, this would have an enormous impact on reducing the number of deaths on the waiting list.

\section{The Role of NMP in Increasing Organ Utilisation}

Over the last 10 years in the UK, the number of livers retrieved but not transplanted has doubled from 8.2 to $16.6 \%$ (8). The situation is somewhat worse in the US, with the Organ Procurement and Transplantation Network reporting that only $78 \%$ of potential donor livers were transplanted (31). Livers are discarded based on reported donor characteristics as well as the gross appearance of the organ (32-34). However, the lack of validated, objective predictors of function inevitably results in organs being turned down that would have functioned if transplanted. As well as reducing IRI and promoting liver regeneration (35), the potential to perform a viability assessment on the liver ex vivo will undoubtedly increase the number of transplanted livers as surgeons can make an objective assessment of a liver's function during preservation, with the potential to predict post-transplant outcomes. Mergental et al recently reported the normothermic reconditioning of 6 livers which had been rejected by all UK liver transplant centres (21). Five of these livers were subsequently transplanted as they demonstrated ex vivo function; specifically lactate clearance, bile production, acid/base homeostasis, stable flow dynamics as well as healthy graft appearance and consistency. At a 
median 7 (range 6-19) months follow-up, all recipients remained well with functioning grafts. Watson et al (36) also published their experience of transplanting livers which had been declined by other UK liver transplant centres, following NMP and assessing organ quality and function. They observed that preserving livers at physiological oxygen tensions resulted in a reduced incidence of post-reperfusion syndrome and suggested the importance of biliary $\mathrm{pH}$ in predicting post-transplant cholangiopathy. The Birmingham group is undertaking a further clinical trial to assess more formally the benefit of NMP in liver grafts declined by other centres. A summary of all registered on-going NMP clinical trials is shown in table 3.

There is some evidence that NMP is particularly beneficial in high-risk sub-groups such as DCD and steatotic livers. Brockmann et al (13) investigated extended preservation times (20 hours) in both DBD and DCD (with 40 min warm ischaemia) porcine models and demonstrated markedly superior outcomes compared with SCS. It is notable that no difference in outcome was seen in DBD livers preserved for only 5 hours, suggesting that the main benefit of NMP might be in high-risk livers. Furthermore, in the COPE RCT, the improvement in early biochemical function observed with NMP livers was greater in the DCD cohort $(p=0.02)(30)$. These data suggest that NMP has a role in reversing energy depletion and the immediate effects of warm ischaemia; this may be a particularly important finding when only around $5-10 \%$ of DCD livers are transplanted in the US and Euro-Transplant regions. It has also been reported in porcine and rodent models of hepatic steatosis that NMP can maintain physiological function compared to lean livers and that the fat content of the liver can be reduced through the use of specific de-fatting agents administered during NMP $(37,38)$.

As well as enhanced preservation and functional liver assessment contributing to increased utilisation, improved logistics might also result in more livers being transplanted. This is attributable to increased preservation times of up to 24hrs on the NMP device which can facilitate a more structured and organized approach to transplantation by improving utilisation of the operating room and elective lists, arranging appropriate staffing levels and facilitating the pre-operative preparation of the recipient.

\section{The Future of NMP}

As experience with this novel technology increases, new questions will be posed. These will refine the way this technology is used and enhance its potential. NMP is logistically more challenging and costlier than SCS, particularly when used for the whole preservation period, 
where dedicated personnel may be required to attend the donor hospital and different arrangements made for transportation. Indeed, Selzner et al acknowledged that the use of NMP prolonged the organ retrieval process by $2 \mathrm{hrs}$ because of back-bench preparation of the liver, cannulation, and connection to the device (28). The majority of NMP livers have been transplanted following perfusion for the entire preservation period from the donor to the recipient. However, it would be logistically more straight-forward and less expensive if livers could be placed on the NMP circuit at the recipient hospital, following a period of SCS, termed post-SCS-NMP (pSCS-NMP) (39). The safety and feasibility of this approach has recently been tested by the Oxford Group in a clinical trial setting with outcomes compared to the NMP and SCS cohorts from the COPE RCT; the detailed results of this study are awaited (table 3). Further studies will be needed to explore: longer-term outcomes; late biliary complications; outcomes in specific high-risk groups; viability biomarkers; optimum and maximum perfusion duration; perfusate composition; and liver-directed therapeutic interventions during NMP. These challenges provide exciting clinical and academic opportunities for those working with this novel technology.

\section{Acknowledgements}

We are grateful to Cristiano Quintini MD and his research team at the Cleveland Clinic and the clinical support teams at Organ Assist and OrganOx Ltd. for providing technical information on their normothermic liver perfusion devices. 


\section{References}

1. Carrel A, Lindbergh CA. The Culture of Whole Organs. Science. 1935;81(2112):621-3.

2. Dutkowski $P$, de Rougemont $O$, Clavien PA. Alexis Carrel: genius, innovator and ideologist. Am J Transplant. 2008;8(10):1998-2003.

3. Belzer FO, Ashby BS, Gulyassy PF, Powell M. Successful seventeen-hour preservation and transplantation of human-cadaver kidney. N Engl J Med. 1968;278(11):608-10.

4. Neuberger J. Liver transplantation in the United Kingdom. Liver Transpl. 2016;22(8):1129-35.

5. Kim WR, Lake JR, Smith JM, Skeans MA, Schladt DP, Edwards EB, et al. OPTN/SRTR 2013 Annual Data Report: liver. Am J Transplant. 2015;15 Suppl 2:1-28.

6. Hassanain M, Simoneau E, Doi SA, Aljiffry M, Aloraini A, Madkhali A, et al. Trends in brain-dead organ donor characteristics: a 13-year analysis. Can J Surg. 2016;59(3):154-60.

7. Orman ES, Barritt ASt, Wheeler SB, Hayashi PH. Declining liver utilization for transplantation in the United States and the impact of donation after cardiac death. Liver Transpl. 2013;19(1):59-68.

8. $\quad$ NHSBT. Annual Report on Liver Transplantation. 2016.

9. Callaghan CJ, Charman SC, Muiesan P, Powell JJ, Gimson AE, van der Meulen JH, et al. Outcomes of transplantation of livers from donation after circulatory death donors in the UK: a cohort study. BMJ Open. 2013;3(9):e003287.

10. Hoyer DP, Paul A, Gallinat A, Molmenti EP, Reinhardt R, Minor T, et al. Donor information based prediction of early allograft dysfunction and outcome in liver transplantation. Liver Int. 2015;35(1):156-63.

11. Foley DP, Fernandez LA, Leverson G, Anderson M, Mezrich J, Sollinger HW, et al. Biliary complications after liver transplantation from donation after cardiac death donors: an analysis of risk factors and long-term outcomes from a single center. Ann Surg. 2011;253(4):817-25.

12. Op den Dries S, Karimian N, Porte RJ. Normothermic machine perfusion of discarded liver grafts. Am J Transplant. 2013;13(9):2504.

13. Brockmann J, Reddy S, Coussios C, Pigott D, Guirriero D, Hughes D, et al. Normothermic perfusion: a new paradigm for organ preservation. Ann Surg. 2009;250(1):1-6.

14. Schon MR, Kollmar O, Wolf S, Schrem H, Matthes M, Akkoc N, et al. Liver transplantation after organ preservation with normothermic extracorporeal perfusion. Ann Surg. 2001;233(1):114-23.

15. Nassar A, Liu Q, Farias K, D'Amico G, Tom C, Grady P, et al. Ex vivo normothermic machine perfusion is safe, simple, and reliable: results from a large animal model. Surg Innov. 2015;22(1):61-9.

16. Ceresa CDL, Nasralla D, Knight S, Friend PJ. Cold storage or normothermic perfusion for liver transplantation: probable application and indications. Curr Opin Organ Transplant. 2017;22(3):300-5.

17. Lanir A, Jenkins RL, Caldwell C, Lee RG, Khettry U, Clouse ME. Hepatic transplantation survival: correlation with adenine nucleotide level in donor liver. Hepatology. 1988;8(3):471-5.

18. Saad S, Minor T. Short-term resuscitation of predamaged donor livers by brief machine perfusion: the influence of temperature. Transplant Proc. 2008;40(10):3321-6.

19. Bessems M, Doorschodt BM, Kolkert JL, Vetelainen RL, van Vliet AK, Vreeling $H$, et al. Preservation of steatotic livers: a comparison between cold storage and machine perfusion preservation. Liver Transpl. 2007;13(4):497-504.

20. Hara Y, Akamatsu Y, Maida K, Kashiwadate T, Kobayashi Y, Ohuchi N, et al. A new liver graft preparation method for uncontrolled non-heart-beating donors, combining short oxygenated warm perfusion and prostaglandin E1. J Surg Res. 2013;184(2):1134-42.

21. Mergental H, Perera MT, Laing RW, Muiesan P, Isaac JR, Smith A, et al. Transplantation of Declined Liver Allografts Following Normothermic Ex-Situ Evaluation. Am J Transplant. 2016.

22. Rosser BG, Gores GJ. Liver cell necrosis: cellular mechanisms and clinical implications. Gastroenterology. 1995;108(1):252-75.

23. Naesens M, Sarwal MM. Molecular diagnostics in transplantation. Nat Rev Nephrol. 2010;6(10):614-28.

24. Ravikumar R, Jassem W, Mergental H, Heaton N, Mirza D, Perera MT, et al. Liver Transplantation After Ex Vivo Normothermic Machine Preservation: A Phase 1 (First-in-Man) Clinical Trial. Am J Transplant. 2016;16(6):1779-87.

25. Glanemann M, Langrehr JM, Stange BJ, Neumann U, Settmacher U, Steinmuller T, et al. Clinical implications of hepatic preservation injury after adult liver transplantation. Am J Transplant. 2003;3(8):1003-9. 26. Eisenbach C, Encke J, Merle U, Gotthardt D, Weiss KH, Schneider L, et al. An early increase in gamma glutamyltranspeptidase and low aspartate aminotransferase peak values are associated with superior outcomes after orthotopic liver transplantation. Transplant Proc. 2009;41(5):1727-30. 
27. Robertson FP, Bessell PR, Diaz-Nieto R, Thomas N, Rolando N, Fuller B, et al. High serum Aspartate transaminase levels on day 3 postliver transplantation correlates with graft and patient survival and would be a valid surrogate for outcome in liver transplantation clinical trials. Transpl Int. 2016;29(3):323-30.

28. Selzner M, Goldaracena N, Echeverri J, Kaths JM, Linares I, Selzner N, et al. Normothermic Ex Vivo Liver Perfusion Using Steen Solution as Perfusate for Human Liver Transplantation-First North American Results. Liver Transpl. 2016.

29. Bral M, Gala-Lopez B, Bigam D, Kneteman N, Malcolm A, Livingstone S, et al. Preliminary Single Centre Canadian Experience of Human Normothermic Ex Vivo Liver Perfusion: Results of a Clinical Trial. Am J Transplant. 2016.

30. Nasralla D CfOPiELRG, Ploeg R, Coussios C, Friend P. Outcomes from a Multinational Randomised Controlled Trial Comparing Normothermic Machine Perfusion with Static Cold Storage in Human Liver Transplantation. American Journal of Transplantation. 2017;17(S3):205-410.

31. Kim WR, Smith JM, Skeans MA, Schladt DP, Schnitzler MA, Edwards EB, et al. OPTN/SRTR 2012 Annual Data Report: liver. Am J Transplant. 2014;14 Suppl 1:69-96.

32. Feng S, Goodrich NP, Bragg-Gresham JL, Dykstra DM, Punch JD, DebRoy MA, et al. Characteristics associated with liver graft failure: the concept of a donor risk index. Am J Transplant. 2006;6(4):783-90.

33. Braat AE, Blok JJ, Putter $\mathrm{H}$, Adam R, Burroughs AK, Rahmel AO, et al. The Eurotransplant donor risk index in liver transplantation: ET-DRI. Am J Transplant. 2012;12(10):2789-96.

34. Collett D, Friend PJ, Watson CJ. Factors Associated With Short- and Long-term Liver Graft Survival in the United Kingdom: Development of a UK Donor Liver Index. Transplantation. 2017;101(4):786-92.

35. Xystrakis E L, Danger R, Martinez-Llordella M, Srinivasan P, Heaton N, Coussios C, Sanchez-Fueyo A, Ma $Y$, Jassem W. Normothemic Machine Perfusion of Liver Grafts Promotes Liver Regeneration and Inhibits Tissue Inflammation. American Journal of Transplantation. 2015;15(S3).

36. Watson CJE, Kosmoliaptsis V, Randle LV, Gimson AE, Brais R, Klinck JR, et al. Normothermic Perfusion in the Assessment and Preservation of Declined Livers Before Transplantation: Hyperoxia and VasoplegiaImportant Lessons From the First 12 Cases. Transplantation. 2017;101(5):1084-98.

37. Jamieson RW, Zilvetti M, Roy D, Hughes D, Morovat A, Coussios CC, et al. Hepatic steatosis and normothermic perfusion-preliminary experiments in a porcine model. Transplantation. 2011;92(3):289-95.

38. Nagrath D, Xu H, Tanimura Y, Zuo R, Berthiaume F, Avila M, et al. Metabolic preconditioning of donor organs: defatting fatty livers by normothermic perfusion ex vivo. Metab Eng. 2009;11(4-5):274-83.

39. Karangwa SA, Dutkowski P, Fontes P, Friend PJ, Guarrera JV, Markmann JF, et al. Machine Perfusion of Donor Livers for Transplantation: A Proposal for Standardized Nomenclature and Reporting Guidelines. Am J Transplant. 2016. 
TABLE 1. TECHNICAL COMPARISON OF NMP DEVICES

\begin{tabular}{|c|c|c|c|c|c|c|c|c|c|}
\hline Device & Arterial Flow & $\begin{array}{l}\text { Pressure } \\
\text { Control }\end{array}$ & Cannulation & $\begin{array}{l}\text { Oxygen } \\
\text { Delivery } \\
\text { Method }\end{array}$ & $\begin{array}{l}\text { Preservation } \\
\text { Duration }\end{array}$ & $\begin{array}{l}\text { Battery } \\
\text { Life }\end{array}$ & Temperature & $\begin{array}{l}\text { Transportable } \\
\text { during preservation }\end{array}$ & $\begin{array}{l}\text { No. of livers } \\
\text { transplanted using } \\
\text { device }\end{array}$ \\
\hline $\begin{array}{l}\text { OrganOx metra }^{\circledR} \\
\text { (OrganOx Ltd, } \\
\text { Oxford, UK). }\end{array}$ & Continuous & Automated & $\begin{array}{l}\text { Hepatic Artery } \\
\text { Portal Vein } \\
\text { IVC } \\
\text { Closed System }\end{array}$ & $\begin{array}{l}\text { On-board } \\
\text { oxygen } \\
\text { concentrator }\end{array}$ & 24hrs & 2-4hrs & Normothermic & Yes & $>240$ \\
\hline $\begin{array}{l}\text { Liver Assist } \\
\text { (Organ Assist, } \\
\text { Groningen, the } \\
\text { Netherlands) }\end{array}$ & Pulsatile & Manual & $\begin{array}{l}\text { Hepatic Artery } \\
\text { Portal Vein } \\
\text { Open IVC } \\
\text { Drainage }\end{array}$ & $\begin{array}{l}\text { External gas } \\
\text { mixer and/or } \\
\text { cylinder }\end{array}$ & $\begin{array}{l}24 \mathrm{hrs} \\
\text { (oxygenator } \\
\text { dependent) }\end{array}$ & $20 \mathrm{mins}$ & $\begin{array}{l}\text { Hypothermic } \\
\text { Sub-normothermic } \\
\text { Normothermic }\end{array}$ & No & $\begin{array}{l}>300 \\
\text { (hypothermic, sub- } \\
\text { normothermic }+ \\
\text { normothermic) }\end{array}$ \\
\hline $\begin{array}{l}\text { OCS }^{\mathrm{TM}} \text { Liver } \\
\text { System } \\
\text { (Transmedics, } \\
\text { Andover, } \\
\text { Massachusetts) }\end{array}$ & \multicolumn{9}{|c|}{ Information not currently available } \\
\hline $\begin{array}{l}\text { Cleveland NMP } \\
\text { Device (Cleveland } \\
\text { Clinic, Ohio) }\end{array}$ & Continuous & Manual & $\begin{array}{l}\text { Hepatic Artery } \\
\text { Portal Vein } \\
\text { Open IVC } \\
\text { Drainage }\end{array}$ & $\begin{array}{l}\text { Mixing air and } \\
\text { pure oxygen }\end{array}$ & 18hrs & $\begin{array}{l}\text { 30mins- } \\
4 \mathrm{hrs}\end{array}$ & $\begin{array}{l}\text { Sub-normothermic } \\
\text { Normothermic }\end{array}$ & Yes & 15 \\
\hline
\end{tabular}


TABLE 2. PUBLISHED MANUSCRIPTS OF TRANSPLANTED NMP LIVERS

\begin{tabular}{|c|c|c|c|c|c|c|c|}
\hline Author & Group & Year Published & Device & Study Design & $\begin{array}{l}\text { No. of livers } \\
\text { transplanted }\end{array}$ & $\begin{array}{l}\text { \%DBD/ } \\
\text { DCD }\end{array}$ & $\begin{array}{l}\text { Primary } \\
\text { Outcome(s) }\end{array}$ \\
\hline $\begin{array}{l}\text { Ravikumar et al } \\
\text { (24) }\end{array}$ & Oxford & 2016 & $\begin{array}{l}\text { OrganOx } \\
\text { metra }^{\circledR}\end{array}$ & $\begin{array}{l}\text { Phase I pilot with } \\
\text { retrospective matched } \\
\text { controls }\end{array}$ & 20 & $\begin{array}{l}80 \% \text { DBD } \\
20 \% \text { DCD }\end{array}$ & $\begin{array}{l}\text { 30-day patient and } \\
\text { graft survival }\end{array}$ \\
\hline Selzner et al (28) & Toronto & 2016 & $\begin{array}{l}\text { OrganOx } \\
\text { metra }^{\circledR}\end{array}$ & $\begin{array}{l}\text { Phase I pilot with } \\
\text { retrospective matched } \\
\text { controls }\end{array}$ & 10 & $\begin{array}{l}80 \% \text { DBD } \\
20 \% \text { DCD }\end{array}$ & $\begin{array}{l}\text { 90-day patient and } \\
\text { graft survival }\end{array}$ \\
\hline Bral et al (29) & Edmonton & 2016 & $\begin{array}{l}\text { OrganOx } \\
\text { metra }^{\circledR}\end{array}$ & $\begin{array}{l}\text { Phase I pilot with } \\
\text { retrospective matched } \\
\text { controls }\end{array}$ & 9 & $\begin{array}{l}66.7 \% \text { DBD } \\
33.3 \% \text { DCD }\end{array}$ & 30-day graft survival \\
\hline $\begin{array}{l}\text { Mergental et al } \\
\text { (21) }\end{array}$ & Birmingham & 2016 & $\begin{array}{l}\text { Liver Assist } \\
\text { OrganOx } \\
\text { metra }^{\circledR}\end{array}$ & Case Series & 5 & $\begin{array}{l}20 \% \text { DBD } \\
80 \% \text { DCD }\end{array}$ & \\
\hline Watson et al (36) & Cambridge & 2017 & Liver Assist & Case Series & 12 & $\begin{array}{l}25 \% \text { DBD } \\
75 \% \text { DCD }\end{array}$ & \\
\hline
\end{tabular}


TABLE 3. ONGOING REGISTERED CLINICAL NMP TRIALS

\begin{tabular}{|c|c|c|c|c|c|c|c|}
\hline Study Title & Study Type & $\begin{array}{l}\text { Estimated } \\
\text { Enrolment }\end{array}$ & Primary Outcome(s) & Start Date & Identifier & Device & Group \\
\hline $\begin{array}{l}\text { Efficacy Evaluation } \\
\text { of NMP in Liver } \\
\text { Transplant using } \\
\text { Very Old Donors } \\
\text { (CEFEMA) }\end{array}$ & $\begin{array}{l}\text { Randomized } \\
\text { Pilot }\end{array}$ & 30 & 6-month graft survival & $\begin{array}{l}\text { October } \\
2016\end{array}$ & NCT02940600 & $\begin{array}{l}\text { Liver Assist (Organ } \\
\text { Assist, Groningen, } \\
\text { the Netherlands) }\end{array}$ & Pisa, Italy \\
\hline $\begin{array}{l}\text { Normothermic Liver } \\
\text { Preservation }\end{array}$ & RCT & 226 & EAD & June 2016 & NCT02775162 & $\begin{array}{l}\text { OrganOx metra }^{\circledR} \\
\text { (OrganOx Ltd, } \\
\text { Oxford, UK). }\end{array}$ & $\begin{array}{l}\text { OrganOx Ltd., } \\
\text { Oxford, UK } \\
\text { NAMSA, USA }\end{array}$ \\
\hline $\begin{array}{l}\text { Post Static Cold } \\
\text { Storage NMP }\end{array}$ & $\begin{array}{l}\text { Phase II } \\
\text { Safety and } \\
\text { feasibility }\end{array}$ & 30 & $\begin{array}{l}\text { 30-day patient and graft } \\
\text { survival }\end{array}$ & May 2017 & NCT03176433 & $\begin{array}{l}\text { OrganOx metra }^{\circledR} \\
\text { (OrganOx Ltd, } \\
\text { Oxford, UK). }\end{array}$ & Oxford, UK \\
\hline $\begin{array}{l}\text { Normothermic Liver } \\
\text { Preservation Trial }\end{array}$ & Phase II & 50 & 30-day graft survival & $\begin{array}{l}\text { February } \\
2017\end{array}$ & NCT03089840 & $\begin{array}{l}\text { OrganOx metra }^{\circledR} \\
\text { (OrganOx Ltd, } \\
\text { Oxford, UK). }\end{array}$ & $\begin{array}{l}\text { Edmonton, } \\
\text { Canada }\end{array}$ \\
\hline $\begin{array}{l}\text { Pilot Study to } \\
\text { Assess Safety and } \\
\text { Feasibility of NMP } \\
\text { in Human Liver } \\
\text { Transplantation }\end{array}$ & Phase I Pilot & 32 & EAD & July 2015 & NCT02515708 & $\begin{array}{l}\text { Cleveland NMP } \\
\text { Device }\end{array}$ & Cleveland, Ohio \\
\hline $\begin{array}{l}\text { Viability Testing } \\
\text { and Transplantation } \\
\text { of Marginal Livers } \\
\text { (VITTAL) }\end{array}$ & $\begin{array}{l}\text { Prospective } \\
\text { Non-randomized }\end{array}$ & 22 & $\begin{array}{l}\text { 90-day patient survival } \\
\text { NMP to identify the } \\
\text { proportion of } \\
\text { transplantable livers from } \\
\text { currently rejected donor } \\
\text { pool }\end{array}$ & $\begin{array}{l}\text { October } \\
2016\end{array}$ & NCT02740608 & $\begin{array}{l}\text { OrganOx metra }^{\circledR} \\
\text { (OrganOx Ltd, } \\
\text { Oxford, UK). }\end{array}$ & Birmingham, UK \\
\hline $\begin{array}{l}\text { TransMedics (OCS) } \\
\text { Liver Trial: } \\
\text { Preserving and } \\
\text { Assessing Donor } \\
\text { Livers for }\end{array}$ & RCT & 300 & $\begin{array}{l}\text { EAD } \\
\text { SAEs }\end{array}$ & $\begin{array}{l}\text { January } \\
2016\end{array}$ & NCT02522871 & $\begin{array}{l}\text { OCS }^{\mathrm{TM}} \text { Liver } \\
\text { System } \\
\text { (Transmedics, } \\
\text { Andover, } \\
\text { Massachusetts) }\end{array}$ & $\begin{array}{l}\text { TransMedics, } \\
\text { Andover, } \\
\text { Massachusetts, } \\
\text { USA }\end{array}$ \\
\hline
\end{tabular}




\begin{tabular}{|c|c|c|c|c|c|c|c|}
\hline $\begin{array}{l}\text { Transplantation } \\
\text { (Liver PROTECT) }\end{array}$ & & & & & & & \\
\hline $\begin{array}{l}\text { Using Ex-vivo } \\
\text { Normothermic } \\
\text { Machine Perfusion } \\
\text { with the OrganOx } \\
\text { Metra }^{\mathrm{TM}} \text { Device to } \\
\text { Store Human Livers } \\
\text { for Transplantation }\end{array}$ & Phase I & 40 & $\begin{array}{l}\text { Rates of: } \\
\text { PNF } \\
\text { Re-transplantation } \\
\text { Recipient Death }\end{array}$ & Dec 2014 & NCT02478151 & $\begin{array}{l}\text { OrganOx metra }^{\circledR} \\
\text { (OrganOx Ltd, } \\
\text { Oxford, UK). }\end{array}$ & Toronto, Canada \\
\hline $\begin{array}{l}\text { Work Package } 2 \\
\text { (WP2) - } \\
\text { Normothermic Liver } \\
\text { Perfusion Vs Cold } \\
\text { Storage in Liver } \\
\text { Transplants }\end{array}$ & RCT & 220 & Peak Serum AST & April 2014 & ISRCTN39731134 & $\begin{array}{l}\text { OrganOx metra }^{\circledR} \\
\text { (OrganOx Ltd, } \\
\text { Oxford, UK). }\end{array}$ & $\begin{array}{l}\text { COPE } \\
\text { Consortium, } \\
\text { Oxford, UK }\end{array}$ \\
\hline
\end{tabular}


